\title{
CHARACTER BUILDING AND LITERACY CULTURE \\ IN PRIMARY EDUCATION \\ (Case Study in SMPN 1 Tulungagung)
}

\author{
Muh. Zainul Arifin \\ IAIN Tulungagung
}

\begin{abstract}
Character building and literacy culture is urgent something and must be done by educational institutions, especially primary educations. In primary education, students are accustomed to good behavior, so that in the end they have good character. Indeed, character building is not easy and cannot be instantly, but with continuous habituation it will produce a character output. This research is qualitative in nature with a type of case study that has a single case study design. This research is qualitative research in education so to understand external reason of character building and literacy culture. The results of this study are the building character and literacy culture in educational institutions carried out in several stages. This research adds a new variant to Kaizen theory, which is intangible value. This research also adds a new variant to the theory of Ndraha, namely the synergy of all citizens of educational institutions and the active role of intangible values.
\end{abstract}

Keyword: Character Building, Literacy Culture, Primary Education

\begin{abstract}
ABSTRAK
Pembangunan karakter dan budaya literasi merupakan sesuatu yang urgen dan harus dilakukan oleh lembaga pendidikan, terutama lembaga pendidikan dasar. Pada lembaga pendidikan dasar, anak didik dibiasakan untuk berperilaku yang baik, sehingga pada akhirnya mempunyai karakter yang baik. Memang pembangunan karakter tidak mudah dan tidak bisa dilakukan secara instan, namun dengan pembiasaan yang terus menerus maka akan menghasilkan output yang berkarakter. Penelitian ini bersifat kualitatif dengan jenis studi kasus yang mempunyai rancangan studi kasus tunggal. Penelitian ini berusaha untuk memahami yang tersirat dibalik yang tersurat. Hasil dari penelitian ini adalah pembangunan karakter dan budaya literasi di lembaga pendidikan dilakukan dengan beberapa tahapan. Penelitian ini menambah varian baru pada teori Kaizen, yaitu nilai intangible. Penelitian ini juga menambah varian baru pada teori Ndraha, yaitu adanya sinergi dari seluruh warga lembaga pendidikan serta peran aktif nilai intangible.
\end{abstract}

Kata Kunci: Pembangunan Karakter, Budaya Literasi, Pendidikan Dasar 


\section{A. INTRODUCTION}

Education is an effort to mature humans in various aspects. Any experience that has a formative effect on the way people think, feel, or act can be considered educational. Education is generally divided into several stages such as preschool, elementary school, secondary school and then college, university or internship. Education is carried out through a variety of processes, both informal, formal and informal. Especially the implementation of education in Indonesia, education is carried out in these three institutions.

However, the practice of education in Indonesia, in the capacity of formal education, tends to be more oriented to education based on hard skills (technical skills) that is education that is more developed intelligence quotient (IQ), but less developedcapabilities soft skills as contained in emotional intelligence (EQ), and spiritual intelligence (SQ). In fact, learning in various schools and even higher education places more emphasis on the acquisition of test scores and exam results or can be said to be oriented on cognitive aspects only. Many people who have the perception that students who have good competence are having high test scores / tests, while those with low test results can be said to not have adequate competence. So no wonder the National Examination (UN) is often used as a reference in the success of students, although not necessarily true.

As time goes by, education which is only based on hard skills is no longer relevant. In fact, if you want to learn from developed countries. Education in developed countries is successful, for example Finland, because it emphasizes the development of soft skills. Even the success of mastering science and technology is also a natural result of the strong foundations of soft skills (Bagir, 2014: 16). So, learning must also be based on the development of soft skills (social interaction) because this is very important in shaping the character of the nation's children so that they are able to compete, be ethical, moral, polite and interact with the community.education is Soft skill based on fostering mentality so that students can adjust to the realities of life. A person's success is not determined solely by knowledge and technical skills (hard skills), but also by the skills to manage themselves and others (soft skills).

Education Character which is one of the means of soft skills that can be integrated in learning in each subject. Learning materials related to norms or values in each subject need to be developed, made explicit, related to the context of daily life. Even in the learning inserted adiwiyata and multicultural values so that awareness grows in students themselves. More than that, every material in a subject 
needs to be integrated with adiwiyata and multicultural characters. Thus, learning of character values is not only at the cognitive level, but touches on internalization, and real practice in the daily lives of students in the community.

This has become important, especially for students in Indonesia in recent decades. Lately students experience a moral crisis, especially in terms of tolerance and environmental awareness. The crisis attacks the younger generation, especially at school age. Indonesian youths are currently experiencing a crisis level of morality, personality and intellect. Even many schoolchildren who often litter, torture animals, ridicule others of different religions and so on. It might be an exaggeration to say so, but it could be that the act is the output of an attitude of not caring about the environment, not caring about other people, loss of courtesy, being far from religion, and all the other 'bad' qualities that are already very acute. In short, our young people are experiencing a mental crisis. Other facts can be called: brawl, drug abuse, free sex and so on.

Meanwhile, the GLS (School Literacy Movement) was developed based on nine priority agendas (Nawacita) related to the duties and functions of the Ministry of Education and Culture, specifically Nawacita numbers 5, 6, 8, and 9. The Nawacita Points meant were (5) to improve the quality of human life and Indonesian society; (6) increasing people's productivity and competitiveness in international markets so that the Indonesian people can advance and rise together with other Asian nations; (8) revolutionizing the nation's character; (9) strengthen diversity and strengthen Indonesian social restoration. The four Nawacita items are closely related to the literacy component as capital for the formation of quality, productive and competitive, character and nationalist human resources.

Starting from that, it is very urgent for educational institutions, especially basic education to instill character to students and also build literacy culture.

\section{B. METHODS}

Looking at the implied meaning of the title and the problems studied, this study is the kind of field research with a qualitative approach, the research did not conduct quantitative data calculations, (Moleong, 2010: 2) the naturalistic paradigm or interpretive. Data is collected fromnatural settingsas a direct data source. Naturalistic paradigm is used because it allows researchers to find meaning (meaning) of each phenomenon so that it is expected to find local wisdom (local wisdom), traditional wisdom (traditional wisdom), moral values (emic, ethical, and noetic) as well as theories of the subject under study. The meaning of data in depth and being able to develop theories can 
only be done if facts are obtained that are sufficiently detailed and can be synchronized with existing theories.

This research design uses a case study type with a single case study design, which seeks to describe a particular setting, object or event in detail and in depth. Case studies are research that aims to study intensively about certain social units, which include individuals, groups, institutions and society (Riyanto, 2001: 64). This research will produce detailed information that might not be obtained in other types of research. The location of this research is SMPN 1 Tulungagung. This school was chosen because this school instills character values to its students in order to create a strong literacy and school culture.

Considering this type of research, the primary data sources in this study are the words and actions of the principal, teachers and the entire academic community of SMPN 1 Tulungagung which have drawn conclusions so as to obtain a temporary conclusion. The selection of this data source is based on the assumption that they are involved in character planting activities to the academic community in character building and literacy culture. Secondary data sources are written documents or material or literature, namely books, articles, scientific journals, and newspapers that discuss issues relevant to this research. Another secondary data source is documentation in the form of photos, for example photos of activities, all activities and facilities and infrastructure that can provide a real picture of the aspects studied, such as deliberation rooms, meeting rooms, learning processes and extra-curricular activities.

The research data will be collected first, through observation, namely by visiting SMPN 1 Tulungagung to notice or observe the activities organized and observe the surrounding environment. Second, collected through interview techniques, namely by means of direct communication and question and answer to the principal and teachers to deepen the information obtained from other data collection techniques. Third, research data will be collected through documentation, both official SMPN 1 Tulungagung documents such as the rules and history of their development, as well as documents from newspapers, magazines or websites about the school.

The data analysis technique used is a descriptive technique by taking three steps that occur simultaneously according to Miles and Huberman, namely:

1) Data reduction, namely classifying, directing, removing unnecessary and organizing data;

2) Data displays, namely: finding meaningful patterns of relationships and providing the possibility of drawing conclusions; and

3) Conclusion drawing or verification (Miles \& Mikel, 1992: 22).

Checking the validity of the data (trustworthiness) in this study uses the opinion of Lincoln and Guba that the implementation 
of checking the validity of the data is based on four criteria, namely the degree of credibility, transferability, dependability and confirmability (Lincoln and Guba, 1958: 289 $331)$.

\section{RESEARCH DISCUSSION} RESULTS

AND

From various data available at SMPN 1 Tulungagung, it can be concluded that multicultural values implanted at SMPN 1 Tulungagung include: honesty, sensitivity, responsibility, discipline, loyalty, loyalty, obedience, and tolerance. While the adiwiyata values that are planted at SMPN 1 Tulungagung include: caring for the environment, love of cleanliness, responsibility, independence and tolerance.

Reality and multicultural values need to be instilled in educational institutions to develop a strong and powerful mental revolution in these educational institutions. With the internalization of the values of multicultural and multicultural awareness of the academic community at SMPN 1 Tulungagung about environmental conservation, maintaining cleanliness and mutual tolerance between the academic community at SMPN 1 Tulungagung will further develop and be well nurtured.

Characters in the Big Indonesian Dictionary are defined as character, temperament and nature the characteristics of someone who distinguishes one person from another (Badudu, 1996: 617). The real character is taken from the Greek, which is charassein, which means carving (Munir, 2011: 2). It means that the character is formed by engraving in one's habits and takes a long time. Character according to Khan is a stable personal attitude resulting from a progressive and dynamic process of consolidation, integration of statements and actions (Khan, 2010: 1). Meanwhile, according to Novak, as quoted by Lickona, the character is a compatible mix of all goodness identified by religious traditions, literary stories, wise men, and a collection of common sense people in history (Lickona, 2012: 81).

Character education is a very important part of being a school assignment, but lacking attention. As a result the lack of attention to character education in the realm of schooling as Lickona argues, has led to the development of various social ills in the community (Almusanna, 2010: 247). Schools should not only be obliged to increase academic achievement but also be responsible for shaping the character of students. To support the development of student character must involve all components in the school both from aspects of curriculum content, learning process, relationship quality, subject handling, implementation of co-curricular activities, and ethos throughout the school environment. In addition to realizing virtue, that is a good quality of humanity is objectively not only 
good for individual individuals, but also for society as a whole.

Character education, according to Ratna Megawangi, is an effort to educate children to be able to take decisions wisely and put them into practice in their daily lives, so that they can make a positive contribution to their environment (Megawangi, 2004).

The character of the nation is a very important aspect of the quality of human resources because the quality of the nation's character determines the progress of a nation. Quality character needs to be shaped and nurtured from an early age. Early childhood is a critical period for the formation of one's character. According to Freud the failure of planting and a good personality at an early age will form a problematic personality in adulthood later (Muslich, 2011: 35. Parents success in guiding their children in overcoming personality conflicts at an early age will determine the child's success in social life in his adult life.

On the other hand the formation of character must be done systematically and continuously involving aspects of knowledge, feeling, loving, and action. Considering the importance of planting characters at an early age and remembering preschool age is a preparation period for real school, it is very important to plant good characters at preschool age.

\section{a. Moral Knowing / Learning To Know}

This stage is the first step in character education. In this stage the goal is oriented to the mastery of knowledge about values. Students must be able to:

a) Distinguish between noble and ignoble moral values and universal values;

b) Understand logically and rationally (not dogmatically and doctrinally) the importance of noble morals and the danger of ignoble morals in life;

c) Know the figure of the Prophet Muhammad. As an exemplary figure of noble character through his hadiths and sunna.

\section{b. Moral Loving / Moral Feeling}

Learn to love by serving others. Learn to love with unconditional love. This stage is intended to foster love and a sense of need for noble moral values. In this stage the teacher's target is the emotional dimension of the student, heart or soul, not reason, reason and logic. The teacher touches students' emotions so that they grow in awareness, desires and needs so that students are able to say to themselves, "yes, I have to be like that ..." or "I need to practice this morals". To reach this stage the teacher can enter it with touching stories, modeling, or contemplation. Through this stage students are expected to be able to 
assess themselves (muhasabah), getting to know their shortcomings.

\section{c. Moral Doing / Learning to do}

This is the peak of the success of moral subjects, students practice these noble moral values in their daily behavior. Students become increasingly polite, friendly, respectful, merciful, honest, disciplined, love, love and affection, just and generous and so on. As long as moral changes have not been seen in the behavior of children even though a little, during that time we also have a pile of questions that must always be sought answers. Example or example is the best teacher in instilling values. Who we are and what we give. The next action is habitually and motivating (UNESCO - UNEVOC, 2005).

According to Thomas Lickona, elements essential character that should be imparted to the students there are seven (7) elements, namely:
a. sincerity or honesty;
b. compassion;
c. Courage;
d. compassion (kindness);
e. Self-controlself;
f. cooperation;
g. hard work (deligence) (Lickona, 2012: 85).

These seven core characters, according to Thomas Lickona, are the most important and fundamental things to be developed in students in addition to the many other character elements. If we analyze from the point of view of the restoration of the life of our nation, the seven characters are indeed very essential elements. Say the element of sincerity or honesty, the nation at this time really needs the presence of citizens who have a high level of honesty. Cultivating dishonesty is one sign of the ten signs of the destruction of a nation according to Lickona.

According to the data obtained, character building and literacy culture in educational institutions is carried out in several stages. The character that is targeted and is the main character developed in SMPN 1 Tulungagung, namely the religious character so that religious culture emerges. While the literacy movement that was pioneered led to a literacy culture.

The concrete form of religious culture that is formed is multicultural religious culture which in the end is able to shape the awareness of ddik participants. Rivai argued, globalization had an impact on competitive advantage in aspects of life. In the context of education, competition to get the best education in academic achievement has become a kind of competition. Multicultural religious values are urgent values to be internalized to students because these values will be able to make students more tolerant and more religious and 
even practice their religious teachings and touch their affection and psychomotor. This working paper discusses the internalization of multicultural religious values by forming multicultural religious cultures so that eventually students will get used to practicing religious values and will become students who respect each other even with other religions (Rifa'i, 2016: 117-133).

Concrete steps to realize religious culture in educational institutions through the role of teachers in providing advice, according to Koentjaraningrat theory, efforts to develop in three levels, namely the level of values adopted, the level of daily practice, and the level of cultural symbols (Koentjoroningrat, 2006: 157).

At the level of values adopted, it is necessary to formulate jointly agreed religious values and need to be developed in educational institutions, to further build commitment and mutual loyalty among all members of educational institutions towards the agreed values (Sahlan, 2010: 85). At this stage consistency is also needed to carry out the agreed values and requires the competence of people who formulate values to give examples of how to apply and manifest values in daily activities.

In the level of daily practice, the agreed religious values are manifested in the form of daily attitudes and behavior by all school members. The development process can be carried out through three stages, namely:
1. The socialization of religious values that is agreed upon as the ideal attitude and behavior to be achieved in the future in educational institutions.

2. The determination of action plans weekly or monthlyas stages and systematic steps to be carried out by all parties in educational institutions that realize the agreed religious values.

3. Giving awards to the achievements of the citizens of educational institutions, such as teachers, education personnel, and students as an effort to habituation (habit formation) that upholds attitudes and behaviors that are committed and loyal to the agreed religious teachings and values. Appreciation does not always mean material (economic), but also in the social, cultural, psychological or other meaning (Muhaimin, 2009: 236).

In the level of cultural symbols, the development that needs to be done is to replace cultural symbols that are less in line with religious teachings and values with religious cultural symbols. Changes in symbols can be done by changing the model of dress with the principle of closing genitalia, installation of students' work, photographs and mottos that contain messages of religious value (Sahlan, 2010: 86) (Fathurrahman, 2015: 217). 
Strategies to familiarize religious values in educational institutions can be done through:

1. Power strategy, namely the strategy of religious culture in educational institutions by using power or through people's power, in this case the role of the head of an educational institution with all its power is very dominant in carrying out change;

2. Persuasive strategy, which is carried out through the formation of opinions and views of the community or citizens of educational institutions;

3. Normative re educative. Norms are rules that apply in society. socialized norms through education norms are coupled with re-education to instill and replace the old paradigm of community institution thinking with new ones (Muhaimin, 2009: 328).

The first strategy was developed through a command and ban orapproach reward and punishment (Sahlan, 2010: 86). Whereas the second and third strategies are developed through habituation, example, and persuasive approaches or inviting citizens in subtle ways, by giving reasons and good prospects that can convince them. The nature of the activity can be in the form of positive actions and positive reactions. It can also be in the form of a projection, that is, making an action on its own initiative, the type and direction of its own determined, but reading the emergence of the actions so that they can contribute to give color and direction to the development. It can also be in the form of antipasti, which is an active act of creating ideal situations and conditions in order to achieve its ideal goals (Muhaimin, 2009: 328-329). In carrying out the actions and strategies above, values are the basis of something to do activities. So in SMPN 1 Tulungagung there are intangible values that are able to move all school members to the success of character building and literacy culture.

In addition, to realize innovation, the application ofvalues intangibles is carried out in five stages, namely: forced, forced, can, then ordinary and eventually become a culture (Kasali, 2010: 150). So in essence coercion is the first step in the mobilization ofvalues intangibles so that it becomes a driving force for character building and literacy culture. Then it can also be said that the character development model and literacy culture apply the kaizen principle. Kaizen is derived from the word KAI meaning improvement and ZEN means good. Biased means Kaizen means improvement. Kaizen is defined as continuous improvement.

\section{CONCLUSION}

From the discussion above, the following conclusions can be concluded: There are several character values internalized in SMPN 1 Tulungagung. In 
internalization, character education is needed. In addition, at SMPN 1 Tulungagung, also The School Literacy Movement is developed in character and culture of literacy in educational institutions carried out in several stages. This study adds a new variant to the Kaizen theory, namely intangible values.This study also adds a new variant to the Ndraha theory, namely the synergy of all citizens of educational institutions the active role of intangible value. 


\section{DAFTAR PUSTAKA}

Almusanna, Revitalisasi Kurikulum Muatan

Lokal Untuk Pendidikan Karakter

Melalui Evaluasi Responsif, dalam jurnal pendidikan dan Kebudayaan, Jakarta:

Balitbang Kementerian Pendidikan

Nasional, vol. 16 edisi khusus III,

Oktober 2010.

Badudu, J.S., dan Sutan Mohammad, Kamus Umum Bahasa Indonesia, Jakarta: Pustaka Sinar Harapan, 1996.

Bagir, Haidar, "Belajar dari Pengalaman

Finlandia" sebuah Pengantar dalam Pasi

Sahlberg, Finnish Lessons: Mengajar

Lebih Sedikit, Belajar Lebih Banyak ala

Finlandia, terj. Ahmad Mukhlis, Jakarta:

Kaifa Learning, 2014.

Fathurrohman, Muhammad, Budaya Religius

dalam Meningkatkan Mutu Pendidikan,

Yogyakarta: Kalimedia, 2015.

Kasali, Rhenald, Myelin: Mobilisasi

Intangibles Menjadi Kekuatan

Perubahan, Jakarta: Gramedia, 2010.

Khan, Yahya, Pendidikan Karakter Berbasis

Potensi Diri: Mendongkrak Kualitas

Pendidikan, Yogyakarta: Pelangi

Publishing, 2010.

Lickona, Thomas, Mendidik untuk Membentuk

Karakter, Jakarta: Bumi Aksara, 2012.
Lickona, Thomas, Mendidik Untuk Membentuk Karakter: Bagaimana Sekolah Dapat Memberikan Pendidikan tentang Sikap Hormat, dan Bertanggung Jawab, terj. Juma Abdu Wamaungo, Jakarta: Bumi Aksara, 2012.

Lincoln, YS., Egon G. Guba, Naturalistic Inquiry, Beverly Hill, Caifornia: Sage Publications, 1985.

M.B., Miles, Huberman A.Mikel, Qualitative Data Analisis, Beverly Hills: SAGE Publication, Inc, 1992.

Megawangi, Ratna, Pendidikan Karakter; Solusi yang Tepat untuk Membangun Bangsa, Bogor: Indonesia Heritage Foundation, 2004.

Moleong, Lexy J., Metode Penelitian Kualitatif, Bandung: Remaja Rosda Karya, 2010.

Muhaimin, Nuansa Baru Pendidikan Islam, Jakarta: Raja Grafindo Persada, 2006.

Muhaimin, Rekonstruksi Pendidikan Islam: Dari Paradigma Pengembangan, Manajemen Kelembagaan, Kurikulum hingga Strategi Pembelajaran, Jakarta: Raja Grafindo Persada, 2009. 
Munir, Abdullah, Pendidikan Karakter: Membangun Karakter dari Rumah, Yogyakarta: Gava Media, 2011.

Muslich, Masnur, Pendidikan Karakter Menjawab Tantangan Krisis Multidimensional, Jakarta: Bumi Aksara, 2011.

Rifa'I, Muh. Khoirul, “Internalisasi Nilai-Nilai Religius Berbasis Multikultural Dalam Membentuk Insan Kamil” dalam Jurnal Pendidikan Agama Islam, Volume 4 Nomor 1Mei 2016.
Riyanto, Yatim, Metodologi Penelitian Pendidikan, Surabaya: SIC, 2001.

Sahlan, Asmaun, Mewujudkan Budaya Religius di Sekolah: Upaya Mengembangkan PAI dari teori ke Aksi, Malang: UIN Maliki Press, 2010.

UNESCO - UNEVOC, Learning to Do (Value for Learning and Working Together in a Globalized World), Germany, 2005. 